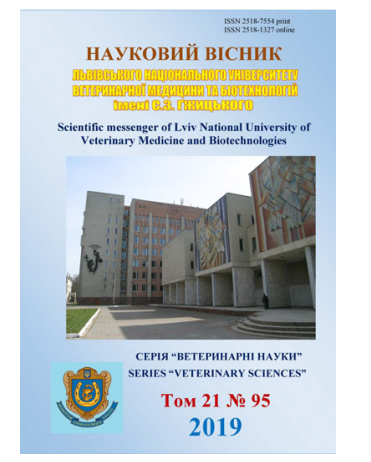

Науковий вісник Дьвівського націонадьного університету ветеринарної медицини та біотехнологій імені С.3. Гжицького. Серія: Ветеринарні науки

Scientific Messenger of Lviv National University of Veterinary Medicine and Biotechnologies. Series: Veterinary sciences

\title{
Effectiveness of modern anthelmintic agents for strongylatoses sheep digestive canal
}

V.V. Melnychuk

Stepan Gzhytskyi National University of Veterinary Medicine and Biotechnologies Lviv, Ukraine

Article info

Received 24.09.2019

Received in revised form 23.10.2019

Accepted 24.10.2019

Stepan Gzhytskyi National University of Veterinary Medicine and Biotechnologies Lviv, Pekarska Str., 50, Lviv, 79010, Ukraine.

Tel.: +38-066-674-78-09 E-mail:melnychyk86@ukr.net
Melnychuk, V.V. (2019). Effectiveness of modern anthelmintic agents for strongylatoses sheep digestive canal. Scientific Messenger of Lviv National University of Veterinary Medicine and Biotechnologies. Series: Veterinary sciences, 21(95), 144-149. doi: 10.32718/nvlvet9527

Currently, the use of anthelmintic agents is considered to be one of the fastest and most practical ways to combat strongylates sheep's digestive tract. Despite the wide assortment of anthelmintic preparations both in the world market and in Ukraine, veterinary specialists are increasingly noticing the low level of efficacy of medicines. Scientists have found that the emergence of resistance in nematodes to the action of anthelmintic agents is due to their excessive and uncontrolled use. In view of the above, regular monitoring of the state of anthelmintic resistance, as part of the program for the control of strongylatoses sheep digestive canal, is a priority area of research. Therefore, the purpose of the study was to evaluate the anthelmintic efficacy of drugs of different chemical groups (benzimidazoles, imidotiazole, macrolides, and combination drugs) for strongylatoses sheep digestive canal with regard to their method of administration. Medicines (Brovalsen, Albendazole-250, Albendazole 10\%; Brovalevamisole 8\%, Levavet 10\%; Univerm, Ivermekvet 1\%; Kloziveron, Kombitrem) have been shown to have anthelmintic action (EE-50-100\%, IE76.20-100\%) against the pathogens of gastrointestinal strongylates. It was noted that their effectiveness depended on the method of administration and the chemical group to which they belonged. The most effective (EE and IE reached 100\%) were injectable drugs Ivermekvet 1\%, Kloziveron and Levavet $10 \%$, administered by single subcutaneous injection. Less effective was the use of a suspension of Albendazole 10\% and Kombitrem emulsion for individual feeding, as well as powders of Brovalevamisole $8 \%$ and the Univerm for both individual and group feeding. The indicators of their EE and $I E$ varied between $60-90 \%$ and $88.45-92.63 \%$ respectively. The Brovalsen drug, which was administered to animals by group feeding, was ineffective, with EE and IE being 50 and $76.20 \%$, respectively. The results of the obtained data will allow to increase the efficiency of conducting therapeutic and preventive measures for strongylatoses digestive canal in sheep farms of different forms of ownership.

Key words: sheep, strongylatoses digestive canal, treatment, anthelmintic drugs, extens- and intenseffectiveness.

\section{Ефективність сучасних антигельмінтних засобів за стронгілятозів травного каналу овець}

\author{
В.В. Мельничук
}

Львівський національний університет ветеринарної медицини та біотехнологій імені С.3. Гљсицкого, м. Львів, Україна

Нині використання антигельмінтних засобів вважається одним із швидких та практичних способів боротьби зі стронгілятами травного каналу овець. Незважаючи на широкий асортимент антигельмінтних препаратів як на світовому ринку, так $і$ в Україні, фахівці ветеринарної медицини все частіше відмічають низький рівень ефективності лікувальних засобів. Науковцями встановлено, що поява резистентності у нематод до дї антигельмінтних засобів обумовлена надмірним та безконтрольним їх використанням. У зв'язку з вищенаведеним регулярний моніторинг стану антигельмінтної резистентності як складової частини 
програми боротьби з стронгілятозами травного каналу овець є пріоритетним напрямом досліджень. Тому метою дослідження було надати очінку антигельмінтної ефективності препаратів різних хімічних груп (бензімідазолів, імідотіазолу, макролідів та комбінованих препаратів) за стронгілятозів травного каналу овець з урахуванням їх способу задавання. Встановлено, ияо лікарські засоби (Бровальзен, Альбендазол-250, Альбендазол 10\%; Бровалевамізол 8\%, Левавет 10\%; Універм, Івермеквет 1\%; Клозіверон, Комбітрем) володіють антигельмінтною дією (ЕE - 50-100\%, IE - 76,20-100\%) щодо збудників шлунково-кишкових стронгілят. Зазначено, шо їхня ефективність залежала від способу задавання та хімічної групи, до якої вони належали. Найбільи ефективними (ЕЕ і ІЕ сягали 100\%) виявилися ін'єкційні препарати Івермеквет 1\%, Клозіверон та Левавет 10\%, які застосовували шляхом одноразового підшкірного введення. Менш ефективним виявилося застосування суспензї Альбендазолу 10\% та емульсії Комбітрему за індивідуального випоювання, а також порошків Бровалевамізолу 8\% та Універму як за індивідуального, так $і$ за групового згодовування. Показники їх ЕE та IE коливалися в межах 60-90\% та 88,45-92,63\% відповідно. Неефективним виявився препарат Бровальзен, який задавали тваринам шляхом групового згодовування, ЕЕ та ІЕ становили 50 та 76,20\% відповідно. Результати отриманих даних дозволять підвищити ефективність проведення лікувальних та профілактичних заходів за стронгілятозів органів травлення у вівцегосподарствах різних форм власності.

Ключові слова: вівиі, стронгілятози травного каналу, лікування, антигельмінтні препарати, екстенс- та інтенсефективHicmb.

\section{Вступ}

Інвазії, викликані шлунково-кишковими нематодами, є найбільш поширеними представниками збудників гельмінтозів, що вражають домашніх овець (Ovis aries Linnaeus, 1758) в усьому світі (Eslami et al., 1976; Dhar et al., 1982; Sevimli, 2013). На значне поширення стронгілятозів травного тракту овець на території різних областей України вказують дані науковців (Byrka \& Berezovskyi, 2003; Bohach et al., 2015; Boyko, 2015; Yevstafieva et al., 2016).

Вчені зазначають, що як наслідок паразитування в організмі овець представників ряду Strongylida, Railliet et Henry, 1913 у тварин знижується загальна резистентність організму, продуктивність, прирости, погіршується товарна якість отримуваної продукції, інколи, внаслідок суперінвазії, хворі тварини гинуть (Safiullin, 1997; Kolesnikov et al., 2001; Ketzis et al., 2002; Githiori et al., 2003; Eguale et al., 2007; Ibrahim et al., 2015).

За даними науковців різних країн світу, найбільш ефективним для боротьби з паразитарними інвазіями тварин вважається використання спеціальних засобів - антигельмінтиків, створених на основі хімічних речовин та їхніх сполук (Borgsteede, 1993; Sargison, 2012; Fishwick \& Dun, 2017; Evans \& Sargison, 2019).

Відомо, що антигельмінтні препарати різних хімічних груп неоднаково діють на збудників гельмінтозних захворювань (Várady et al., 2011; Whitley et al., 2018). Так, дослідниками в різні часи було встановлено низький рівень ефективності ряду препаратів, які належать до різни хімічних груп. До препаратів 3 групи бензімідозолу виявилися стійкими нематоди видів Haemonchus contortus (Cawthorne \& Cheong, 1984; Pandey \& Sivaraj, 1994), Ostertagia circumcincta та Trichostrongylus colubriformis, (Leathwick et al., 1997), Nematodirus sp. (Obendorf et al., 1991).

Щодо препаратів групи імідотіазолів стійкими виявилися нематоди видів Ostertagia consisting, O. circumcincta, O. trifurcata (Jambre, 1979), Haemonchus contortus (Forsyth \& Gibbon, 1980) та роду Trichostrongylus (Webb, \& Ottaway, 1986). Водночас нематоди Haemonchus contortus та Trichostrongylus sp. (Artho et al., 2007), Haemonchus placei, Cooperia punctata, C. pectinata, C. spatulata та Oesophagostomum radiatum
(Borges et al., 2015) виявилися резистентними щодо препаратів групи макролідів.

Враховуючи вищенаведене, важливим залишається питання вивчення ефективності препаратів різних хімічних груп щодо нематодозів травного каналу овець на території України. Тому вважаємо, що дослідження щодо визначення ефективності препаратів різних хімічних груп за нематодозів травного каналу овець на території України $є$ актуальним напрямом роботи.

Мета роботи полягала у встановленні ефективності антигельмінтних препаратів за стронгілятозів травного каналу овець.

Завдання дослідження: дослідним шляхом визначити лікувальну ефективність антигельмінтних препаратів за стронгілятозів травного каналу овець 3 урахуванням хімічної групи, до якої вони належать, та способу їх введення в організм тварини.

\section{Матеріал і методи досліджень}

Дослідження проводили в літньо-осінній період 2019 р. на базі лабораторії кафедри паразитології та ветеринарно-санітарної експертизи Полтавської державної аграрної академії.

Експериментальні дослідження проводили в умовах приватного фермерського господарства Полтавської області на вівцях романівської породи віком 8 міс. - 3 роки, спонтанно інвазованих збудниками стронгілятозів травного тракту за високої інтенсивності інвазії (від 510,00 \pm 28,67 до 595,00 \pm 34,52 яєць/г фекалій (ЯГФ). Інвазованість тварин визначали за кількісним методом з використанням камери Мак Мастера.

Було сформовано дванадцять дослідних і одну контрольну групи тварин по десять голів у кожній. Вівцям першої дослідної групи згодовували груповим способом "Бровальзен порошок” у вигляді лікувально-кормової суміші (ЛКС) із сухим кормом у дозі 0,7 г/10 кг маси тіла одноразово. Вівцям другої дослідної групи згодовували індивідуально “Бровальзен порошок” у вигляді ЛКС із сухим кормом у дозі 0,7 г/10 кг маси тіла одноразово. Вівцям третьої дослідної групи згодовували індивідуально таблетки “Альбендазол-250” у вигляді ЛКС із сухим кормом у дозі 0,2 г/10 кг маси тіла одноразово. Вівцям четвертої дослідної групи випоювали індивідуально препа- 
рат “Альбендазол 10\% суспензія” з водою до початку вранішньої годівлі у дозі 0,5 мл/10 кг маси тіла одноразово. Вівцям п’ятої дослідної групи згодовували груповим способом препарат "Бровалевамізол 8\% порошок" у вигляді ЛКС із сухим кормом у дозі 1 г/10 кг маси тіла одноразово. Вівцям шостої дослідної групи згодовували індивідуально препарат "Бровалевамізол 8\% порошок” у вигляді ЛКС із сухим кормом у дозі 1 г/10 кг маси тіла одноразово. Вівцям сьомої дослідної групи вводили підшкірно препарат “Левавет $10 \%$ розчин для ін'єкцій” у дозі 0,75 мл/10 кг маси тіла одноразово. Вівцям восьмої дослідної групи згодовували груповим способом препарат "Універм" у вигляді ЛКС із сухим кормом у дозі 6 г/10 кг маси тіла дві доби поспіль. Вівцям дев'ятої дослідної групи згодовували індивідуально препарат “Універм” у вигляді ЛКС із сухим кормом у дозі 6 г/10 кг маси тіла дві доби поспіль. Вівцям десятої дослідної групи вводили підшкірно препарат “Івермеквет 1\% розчин для ін'єкцій” у дозі 0,5 мл/25 кг маси тіла одноразово. Вівцям одинадцятої дослідної групи випоювали індивідуально препарат "Комбітрем емульсія" з водою до початку вранішньої годівлі у дозі 0,75 мл/10 кг маси тіла одноразово. Вівцям дванадцятої дослідної групи вводили підшкірно препарат “Клозіверон розчин для ін'єкцій” у дозі 0,5 мл/25 кг маси тіла одноразово. Овець контрольної групи не лікували.

Дослідні та контрольні тварини протягом періоду досліджень перебували в аналогічних умовах годівлі й утримання.

Ефективність лікарських засобів встановлювали на 7 та 14 добу після їх застосування. Головними показниками дії препаратів були екстенсефективність (ЕE) та інтенсефективність (IE).

Оцінку ефективності препаратів проводили за показниками: вище 98\% - високоефективний лікарський засіб; 90-98\% - ефективний; 80-89\% - помірно ефективний; нижче $80 \%$ - недостатньо ефективний або неефективний.

Рівень інвазованості тварин яйцями гельмінтів встановлювали за міжнародною шкалою інвазованості жуйних тварин, згідно якої низькою вважається зараженість 100, середньою - до 500, високою - більше 500 ЯГФ (Whitlock et al., 1980).

\section{Результати та їх обговорення}

За даними загальноклінічних спостережень встановлено, що після застосування антигельмінтиків побічних явищ у тварин упродовж експерименту не виявлено.

Так, за результатами копроскопії найбільш ефективними (ЕE та IE - 100\%) виявилися ін'єкційні форми препаратів, що відносилися до груп імідотіазолу (Левавет 10\%), макролідів (Івермеквет 1\%) та комбінованих засобів (Клозіверон). Інші препарати володіли антигельмінтними властивостями щодо збудників стронгілятозів травного тракту, проте 100\% ефекту вони не давали.
Так, використання препаратів з групи бензімідазолу призводило до часткового звільнення організму овець від збудників стронгілятозів травного каналу, про що свідчать показники їх ефективності (рис. 1).

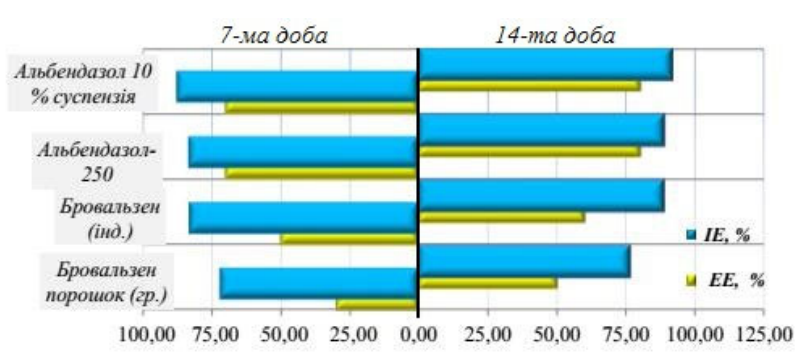

Рис. 1. Терапевтична ефективність антигельмінтних засобів групи бензімідазолу за нематодозів травного каналу овець $(\mathrm{n}=10)$

Найбільш ефективним в цій групі препаратів виявилося використання 10\% суспензії Альбендазолу. Так на 7-му добу досліду ЕЕ препарату становила $70 \%$ за IE - 87,48\%, на 14-ту добу ці показники $\mathrm{EE} \mathrm{ті}$ IE зросли до 80 та 91,47\% відповідно. Меншу ефективність отримано за використання Бровальзену у вигляді порошку та Альбендазолу-250 у вигляді таблеток та таких, що застосовували шляхом одноразового індивідуального згодовування у вигляді ЛКС із сухим кормом. Їх показники ЕE на 7-му добу становили 50 та $70 \%$ за IE 83,04 та 83,19\% відповідно. На 14-ту добу ЕЕ препаратів незначно зросла та дорівнювала для Бровальзену 60\%, для Альбендазолу-250 - 80\%, а показники IE відповідно становили 88,45 та 88,55\%. Найнижчі результати отримано за використання порошку Бровальзен, який застосовували хворим тваринам шляхом групового згодовування. ЕЕ препарату на 7-му добу була на рівні $30 \%$, а на 14 -ту - $50 \%$ за IE 71,93 та 76,20\% відповідно.

Аналізуючи показники ефективності препаратів 3 групи імідотіазалу встановлено, що найдієвішим (EЕ, $\mathrm{IE}-100 \%$ ) виявилося використання розчину Лувавет $10 \%$, який застосовували одноразово шляхом підшкірного введення (рис. 2).

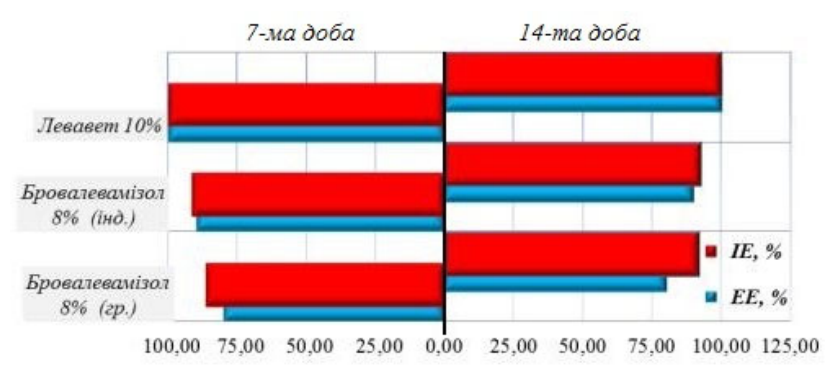

Рис. 2. Терапевтична ефективність антигельмінтних засобів групи імідотіазолу за нематодозів травного каналу овець $(\mathrm{n}=10)$

Варто зазначити, що використання з лікувальною метою порошку Бровалевамізолу $8 \%$ у вигляді ЛКС із сухим кормом виявилося менш ефективним порівняно 3 ін'єкційним введенням препарату Левавет $10 \%$. Так 
індивідуальне згодовування хворим вівцям порошку Бровалевамізолу 8\% призводило до зниження показників його лікувальної ефективності. Рівень ЕЕ засобу як на 7-му, так й на 14-ту доби становив $90 \%$ за IE 91,74 та 92,50\% відповідно.

Встановлено, що групове згодовування порошку Бровалевамізолу 8 \% мало найнижчі показники лікувальної ефективності. ЕЕ препарату на 7-му та 14-ту доби становила $80 \%$, а IE на 7 -му добу $-86,57 \%$, на 14-ту $-91,82 \%$.

Аналізуючи рівень ефективності препаратів, що належать до макролідів та комбінованих засобів, встановлено найбільшу ефективність (ЕE, IE - 100\%) препаратів Левавет 10\% та Клозіверон, які застосовували одноразово шляхом підшкірного введення (рис. 3).

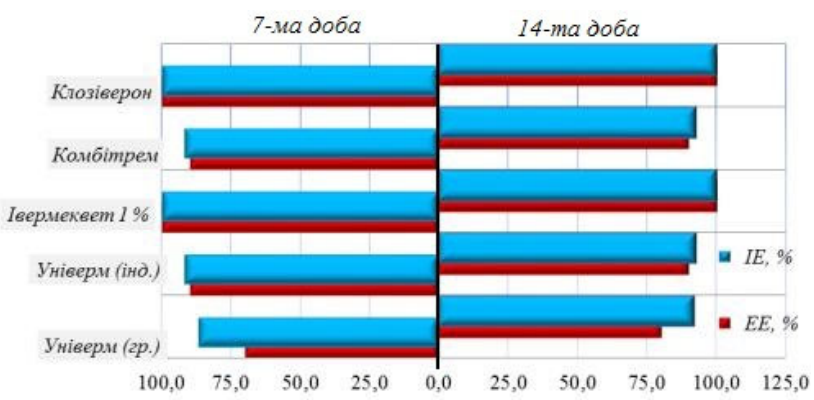

Рис. 3. Терапевтична ефективність антигельмінтиків групи макролідів та комбінованих препаратів за нематодозів травного каналу овець $(\mathrm{n}=10)$

Водночас застосування Універму груповим способом та індивідуально призводило до зниження показників його лікувальної ефективності. ЕЕ препаратів за різних способів застосування становила на 7-му добу - 70 та $90 \%$ за IE - 86,82 та $91,81 \%$, а на 14-ту добу досліду ЕЕ - 80 та 90\% за IE - 92,02 та 92,56\%.

Дещо дієвішим виявилося використання препарату Комбітрем емульсії, який у своєму складі має декілька діючих речовин. Так показник ЕЕ препарату залишався незмінним протягом періоду досліду та становив 90\%. Водночас IE засобу на 14-ту добу досліду незначно зросла й становила 92,63\% порівняно 3 показником на 7-му добу $(91,88 \%)$.

Таким чином, згідно з міжнародною класифікацією антигельмінтних засобів, до високоефективних (вище ніж 98\%) зараховано використання препаратів Івермеквету $1 \%$, Клозіверону та Левавету 10\% шляхом підшкірного введення. До категорії ефективних засобів (90-98\%) належить використання суспензії Альбендазолу 10\% та емульсії Комбітрему за індивідуального випоювання, а також порошок Бровалевамізол 8\% та Універм як за індивідуального, так і за групового згодовування. Помірно ефективним (80-89\%) виявилося використання таблеток Альбендазолу-250 та порошку Бровальзену шляхом індивідуального згодовування у вигляді ЛКС. Неефективним (нижче ніж 80\%) виявилося групове згодовування у вигляді ЛКС порошку Бровальзену.
Аналізуючи літературні дані, можна зазначити, що більшість наукових праць, які стосуються вивчення ефективності антигельмінтних препаратів щодо стронгілятозів травного каналу овець, висвітлено в зарубіжних країнах (McKenna, 2010; Ploeger \& Everts, 2018; Vohra et al., 2019) і лише окремі праці - в нашій державі (Bohach et al., 2015), тому проведені у цьому напрямі дослідження, без сумніву, $є$ унікальними.

Оригінальність проведених нами досліджень полягає в тому, що робота розкриває фактичну ефективність антигельмінтних сучасних препаратів, які зареєстровані на території України та належать до 4-х різних хімічних груп (бензімідазолів, імідотіазолу, макролідів та комбінованих препаратів). Загалом досліджено ефективність 9-ти препаратів. Окрім того, в роботі висвітлено порівняльну характеристику ефективності використання порошкоподібних препаратів залежно від способу задавання (групова та індивідуальна терапія). У жодній із зарубіжних статей авторами не розглядалося питання впливу способу задавання препаратів тваринам на рівень їхньої ефективності.

Отже, дослідженнями встановлено, що препарати 3 групи бензімідазолів незалежно від способу їх задавання не викликають 100\% загибелі стронгілят травного каналу овець. Аналогічні дані у своїй праці показали науковці з Малайзії (Chandrawathani et al., 1999). Варто зауважити, що ефективність препаратів групи імідотіазолу, макролідів та комбінованих засобів залежала від способу їх задавання. Найбільш ефективним за стронгілятозів травного каналу овець виявилося використання ін'єкційних форм препаратів Івермеквету $1 \%$, Левавету $10 \%$ та Клозіверону (EE, IE $100 \%$ ). Менш ефективним було застосування препаратів 3 цих груп у вигляді порошкоподібних форм та суспензії, що знаходить підтвердження у роботах науковців (Pandey, \& Sivaraj, 1994; Kubalieva \& Karmaliev, 2016; Varadharajan et al., 2019).

Таким чином, отримані дані дозволяють здійснити обгрунтований підбір сучасних антигельмінтних засобів за стронгілятозів травного каналу овець з урахуванням їх визначеної антигельмінтної ефективності.

\section{Висновки}

Встановлено, що тестовані препарати (Бровальзен порошок, Альбендазол-250, Альбендазол 10\%, Бровалевамізол 8\%, Левавет 10\%, Універм, Івермеквет 1\%, Комбітрем та Клозіверон) володіють нематоцидними властивостями щодо збудників стронгілятозів шлунково-кишкового тракту овець. Доведено, що використання препаратів Івермеквету 1\%, Клозіверону та Левавету $10 \%$ шляхом підшкірного введення призводило до 100\% лікувальної ефективності. Менш ефективним (EE - 60-90\%, IE - 88,45-92,63\%) виявилося оральне застосування суспензії Альбендазолу 10\%, емульсії Комбітрему, порошку Бровалевамізолу 8\% та Універму як за індивідуального, так й групового згодовування, а також таблеток Альбендазолу-250 та порошку Бровальзену за індивідуального згодовуван- 
ня. Неефективним виявилося групове згодовування порошку Бровальзену (ЕE -50\%, IE - 76,20\%).

Перспективи подальших досліджень. В перспективі планується встановити лікувальну ефективність досліджуваних препаратів за трихурозу овець.

\section{References}

Artho, R., Schnyder, M., Kohler, L., Torgerson, P.R., \& Hertzberg, H. (2007). Avermectin-resistance in gastrointestinal nematodes of Boer goats and Dorper sheep in Switzerland. Veterinary Parasitology, 144(12), 68-73. doi: 10.1016/j.vetpar.2006.09.032.

Bohach, M.V., Bohach, T.V, Bondarenko, L.V., \& Piven, O.T. (2015). Vikova dynamika kyshkovykh parazytoziv ovets $\mathrm{v}$ hospodarstvakh Odeskoi oblasti. Problemy Zooinzhenerii ta Veterynarnoi Medytsyny, 30(2), 213-217 (in Ukrainian).

Borges, F.deA., Borges, D.G.L., Heckler, R.P., Neves, J.P.L., Lopes, F.G., \& Onizuka, M.K.V. (2015). Multispecies resistance of cattle gastrointestinal nematodes to long-acting avermectin formulations in Mato Grosso do Sul. Veterinary Parasitology, 212(34), 299-302. doi: 10.1016/j.vetpar.2015.06.015.

Borgsteede, F.H.M. (1993). The efficacy and persistent anthelmintic effect of ivermectin in sheep. Veterinary Parasitology, 50(1-2), 117-124. doi: 10.1016/03044017(93)90012-c.

Boyko, A.A., (2015). Gel'mintofauna ovets i koz Dnepropetrovskoj oblasti. Vìsnik Dnìpropetrovs'kogo Unìversitetu. Serìâ Bìologîâ, Medicina, 6(2), 87-92 (in Ukrainian).

Byrka, V.I., \& Berezovskyi, A.V. (2003). Parazytofauna molodniaka ovets. Problemy Zooinzhenerii ta Veterynarnoi Medytsyny. Veterynarni Nauky, 35(2), 72-75 (in Ukrainian).

Cawthorne, R., \& Cheong, F. (1984). Prevalence of anthelmintic resistant nematodes in sheep in southeast England. Veterinary Record, 114(23), 562-564. doi: $10.1136 / v r .114 .23 .562$.

Chandrawathani, P., Adnan, M., \& Waller, P.J. (1999). Anthelmintic resistance in sheep and goat farms on Peninsular Malaysia. Veterinary Parasitology, 82(4), 305-310. doi: 10.1016/s0304-4017(99)00028-x.

Dhar, D.N., Sharma, R.L., \& Bansal, G.C. (1982). Gastrointestinal nematodes in sheep in Kashmir. Veterinary Parasitology, 11(2-3), 271-277. doi: 10.1016/03044017(82)90051-6.

Eguale, T., Tilahun, G., Debella, A., Feleke, A., \& Makonnen, E. (2007). Haemonchus contortus: In vitro and in vivo anthelmintic activity of aqueous and hydro-alcoholic extracts of Hedera helix. Experimental Parasitology, 116(4), 340-345. doi: 10.1016/j.exppara.2007.01.019.

Eslami, A., Meydani, M., Maleki, S., \& Zargarzadeh, A. (1979). Gastrointestinal nematodes of wild sheep (Ovis orientalis) from Iran. Journal of Wildlife Diseases, 15(2), 263-265. doi: 10.7589/0090-355815.2.263.
Evans, M., \& Sargison, N. (2019). Planning anthelmintic treatments to control gastrointestinal nematode infections in sheep. Livestock, 24(2), 4-8. doi: 10.12968/live.2019.24.sup2.4.

Fishwick, J., \& Dun, K. (2017). Reclassification of sheep anthelmintic. Veterinary Record, 181(11), 300-301. doi: $10.1136 / v r . j 4260$.

Forsyth, B.A., \& Gibbon, A.J. (1980). The anthelmintic efficacy of half-dose rates of levamisole against benzimidazole resistant haemonchus contortus. Australian Veterinary Journal, 56(4), 203-204. doi: 10.1111/j.1751-0813.1980.tb05692.x.

Githiori, J.B., Höglund, J., Waller, P.J., \& Baker, R.L. (2003). The anthelmintic efficacy of the plant, Albizia anthelmintica, against the nematode parasites Haemonchus contortus of sheep and Heligmosomoides polygyrus of mice. Veterinary Parasitology, 116(1), 23-34. doi: 10.1016/s03044017(03)00218-8.

Ibrahim, M.I.S., Glamazdin, I.G, \& Sysoeva, N.Yu. (2013). Vliyanie gelmintozov na kachestvo myasa ovec. Rossijskij Parazitologicheskij Zhurnal, 2, 54-57 (in Russian).

Jambre, L.F.L. (1979). Effectiveness of anthelmintic treatments against levamisole-resistant Ostertagia. Australian Veterinary Journal, 55(2), 65-67. doi: 10.1111/j.1751-0813.1979.tb15164.x.

Ketzis, J., Taylor, A., Bowman, D., Brown, D., Warnick, L., \& Erb, H. (2002). Chenopodium ambrosioides and its essential oil as treatments for Haemonchus contortus and mixed adult-nematode infections in goats. Small Ruminant Research, 44(3), 193-200. doi: 10.1016/s0921-4488(02)00047-0.

Kolesnikov, V.I., Starikov, I.A., Chetvertnov, V.I., \& Lokteva, M.S. (2001). E'konomicheskij ushherb pri gel'mintozax. Veterinary Medicine, 10, 12 (in Russian).

Kubalieva, M., \& Karmaliev, R. (2016). Effectiveness of anthelmintic helminthiasis of the digestive tract of cattle in West Kazakhstan region. Russian Journal of Parasitology, 3(1), 98-101. doi: 10.12737/18368.

Leathwick, D.M., Miller, C.M., Vlassoff, A., \& Sutherland, I.A. (1997). The death rate of Ostertagia circumcincta and Trichostrongylus colubriformis in lactating ewes: Implications for anthelmintic resistance. International Journal for Parasitology, 27(4), 411-416. doi: 10.1016/s0020-7519(96)001932.

McKenna, P. (2010). Update on the prevalence of anthelmintic resistance in gastrointestinal nematodes of sheep in New Zealand. New Zealand Veterinary Journal, 58(3), 172-173. doi: 10.1080/00480169.2010.67520.

Obendorf, D., Nicholls, J., Koen, T., \& Lacey, E. (1991). Benzimidazole-resistant Nematodirus sp in Tasmania. Australian Veterinary Journal, 68(2), 72-73. doi: 10.1111/j.1751-0813.1991.tb03142.x.

Pandey, V.S., \& Sivaraj, S. (1994). Anthelmintic resistance in Haemonchus contortus from sheep in Malaysia. Veterinary Parasitology, 53(1-2), 67-74. doi: 10.1016/0304-4017(94)90018-3. 
Ploeger, H.W., \& Everts, R.R. (2018). Alarming levels of anthelmintic resistance against gastrointestinal nematodes in sheep in the Netherlands. Veterinary Parasitology, 262, 11-15. doi: 10.1016/j.vetpar.2018.09.007.

Safiullin, R.T. (1997). Rasprostranenie i ekonomicheskij usherb ot osnovnyh gelmintozov zhvachnyh zhivotnyh. Veterinariya, 6, 28-32 (in Russian).

Sargison, N.D. (2012). Pharmaceutical treatments of gastrointestinal nematode infections of sheep-Future of anthelmintic drugs. Veterinary Parasitology, 189(1), 79-84. doi: 10.1016/j.vetpar.2012.03.035.

Sevimli, F. (2013). Checklist of small ruminant gastrointestinal nematodes and their geographical distribution in Turkey. Turkish Journal of Veterinary and Animal Sciences, 37, 369-379. doi: 10.3906/vet1202-15.

Varadharajan, A., Gnanasekar, R., \& Vijayalakshmi, R. (2019). Anthelmintic resistance in naturally infected sheep flocks of Cuddalore district, Tamil nadu. International Journal of Scientific and Research Publications (IJSRP), 9(1), p8517. doi: 10.29322/ijsrp.9.01.2019.p8517.

Várady, M., Papadopoulos, E., Dolinská, M., \& Königová, A. (2011). Anthelmintic resistance in parasites of small ruminants: sheep versus goats.
Helminthologia, 48(3), 137-144. doi: 10.2478/s11687-011-0021-7.

Vohra, S., Singh, S., \& Kumar, V. (2019). Status of Anthelmintic Resistance of Fenbendazole, Closantel and Levamisole against Gastrointestinal Nematodes in Sheep of Haryana. International Journal of Livestock Research, 9(3), 91-96. doi: 10.5455/ijlr.20180802024321.

Webb, R.F., \& Ottaway, S.J. (1986). The prevalence of anthelmintic resistance in sheep nematodes on the central tablelands of New South Wales. Australian Veterinary Journal, 63(1), 13-16. doi: 10.1111/j.17510813.1986.tb02863.x.

Whitley, N., Schoenian, S., O'Brien, D., \& Howell, S. (2018). PSVI-40 Anthelmintic Resistance Testing on Sheep Farms. Journal of Animal Science, 96(3), 467467. doi: 10.1093/jas/sky404.1020.

Whitlock, H.V., Kelly, J.D., Porter, C.J., Griffin, D.L., \& Martin, I.C.A. (1980). In vitro field screening for anthelmintic resistance in strongyles of sheep and horses. Veterinary Parasitology, 7(3), 215-232. doi: 10.1016/0304-4017(80)90026-6.

Yevstafieva, V.O., Hryshko, A.O., \& Perebyinis, O.V. (2016). Nematodiroz u skladi mikstinvazii travnoho kanalu ovets $\mathrm{v}$ umovakh hospodarstv Poltavskoi oblasti. Problemy Zooinzhenerii ta Veterynarnoi Medytsyny, 33(2), 131-134 (in Ukrainian). 